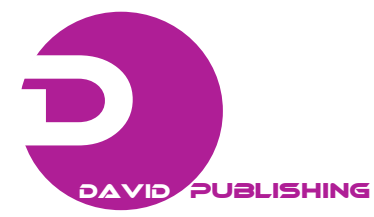

\title{
Experimental Study of Antispasmodic Activity of 2-Oksoindolin-3-Glyoxylic Acid Derivatives
}

\author{
Lutsenko Ruslan Volodymyrovych and Sydorenko Antonina Hryhorivna \\ Higher State Educational Establishment of Ukraine, Ukrainian Medical Dental Academy, Poltava
}

Received: December 16, 2014 / Accepted: January 11, 2014 / Published: June 25, 2014.

\begin{abstract}
Clinical psychiatry and neurology requires a creation of new means with difficult many component range of psychotropic action, so psychoemotional disturbances "boundary type" and difficult mental disorders have high level of heterogeneity, various clinical manifestations, which are caused by different pathogenetic factors. One of the most often used preparation for the treatment of these diseases is anxiolytic medications. It is known that anxiolytic action combines with anticonvulsive. Perspective medications are simple amides and ethers of 2-oksoindolin-3-glyoxylic acid, which have not recognized and practically observed. The aim of this research is to determine anticonvulsant action in 2-oksoindolin-3-glyoxylic acid derivatives on the model of acute myoclonic pentylentetrazol, piktrotoxic, and bikukullin convulsions. In experiments on mature mice of both sex Wistar line were studied an influence of ethyl ester 4-[2-hydroxy-2-(2-oxo-1,2-dihydro-indol-3-ylidene)-acetylamino]-butyric acid and 2-hydroxy- $N$-naphthalen-1-yl-2-(2-oxo-1,2-dihydro-indol-3-ylidene)-acetamide on chemoinduced epileptogenesis. An intake of proconvulsants is accompanied by a development of syndrome convulsion, which was estimated by convulsion's intensity (grades), latent period of convulsions (sec.), number of convulsions acts, and duration of convulsions (sec.) and number of survived animals in a group. It was showed that a combination of 2-hydroxy- $N$-naphthalen-1-yl-2-(2-oxo-1,2-dihydro-indol-3-ylidene)-acetamide (12 acetamide $\mathrm{mg} / \mathrm{kg})$ is similar to reference preparation diazepam in $(2 \mathrm{mg} / \mathrm{kg})$ which decreased a manifestation of syndrome convulsion. It demonstrated an increase of intensity of convulsions, decrease of latent period of the convulsion's start which is caused by all blockers $\mathrm{GAMK}_{\mathrm{A}}$-receptors, decrease of number convulsive acts on the background of korazol and pikrotoxin, a decrease of convulsive syndrome duration during an intake of korazol and bikukullin, and a decrease of animal's mortality, which was caused by pikrotoxin intake.
\end{abstract}

Key words: 2-Oksoindolin derivatives, experimental syndrome of convulsions, korazol, pikrotoxin, bikukullin, pharmoprevention, GABA system.

\section{Introduction}

Dangerous disturbances contain medical, social and economical problem which is used among different disorders of mental activity [1]. In countries of Eurounion, the spread of dangerous disturbances contain about $15 \%$ in all population [2]. Necessity of neurotic pathology is approved by peculiarities, for which chronic duration is characterized. Left untreated, this pathology passes into chronic one, it is often progressed that can lead to small percent of cure [3]. Dangerous disturbances are caused by social and

Corresponding author: Lutsenko Ruslan Volodymyrovych, research fields: neuropsychopharmacology and stress psychocorrection. E-mail: farmalu@mail.ru. professional disadaptation to disability and reduction of life's quality. The third parts of costs are caused by mental disorders and can be a part of psychiatric diseases [4]. Mental disorders are caused by depressive symptomatology, considerably complicate prognosis and lead to suicide and difficult somatic pathology [5].

The most frequently anxiolytic means, according to mental disorders, it is prescribed only at subclinical and completed psychopathological conditions. Means for correction of mental functions, besides psychiatry are widely used by specialists of different fields of medicine and are a part of therapy's standards by many somatic diseases [6].

The usage of traditional anxiolytic preparations can 
be difficult because of development of side effects and possible complications which are serious and connected with high addictive potential, especially it concerns with benzidiasapazapine derivatives. At prescription of atypical tranquilizators wanted effect can be not at once, it requires an individual sensitivity to the preparation which is estimated very difficult.

Perspective investigations are research in the field of pharmacological properties of new chemical combinations especially of 2-oksoindolin-3-glyoxylic acid derivatives. Indole derivatives have such properties of natural inhibitors monoamine oxidase and due to structural similarity they are capable in CNS interrelate with serotonin $\alpha$-adrenoreceptors and dofamine receptors [7]. Indole alkaloids can interrelate with $\mu$-opiod receptors, $\mathrm{GABA}_{\mathrm{A}}$-receptors, NMDA-receptors, conversingly inhibit into acetylcholinesterase [8].

2-oksoindolin-3-glyoxylic acid derivatives have antihypoxic, antianxiolytic, stressprotective activity, and ability of modification behavior reactions and have an influence on emotional sphere among animals. In the basis of such effects there is neurotropic activity.

That's why it is necessary to identify a presence in more perspective combinations anticonvulsant activity, which is often accompanied by antianxiolytic one. The aim of the research is to determine anticonvulsant activity in 2-oksoindolin-3-glyoxylic acid derivatives on the model of acute myoclonic pentylentetrazol, piktrotoxic, and bikukullinic convulsions.

\section{Materials and Methods}

Experiments were held on mature mice of both sex of Wistar line, groups of animals were $(n=10)$ randomized according to the sex and age. Mice were in vivarium at natural light and standard alimentary ration into plastic cages. There were five mice in every cage. All investigations were provided with observations of bioethical requirements and recommendations of European convention of vertebrate's defense, which are used in experimental and other research purposes.
Experimental investigation was performed in spring time at 9 o'clock and one looked parallel for animals with each group individually. Investigations were provided in similar conditions, in isolated building beyond out of external noise.

2-Oksoindolin derivatives these substances of ethyl ether 4-[2-hydroxy-2-(2-oxo-1,2-dihydro-indol-3ylidene)-acetylamino]-butyric acid (connection E-38) and 2-hydroxy- $N$-naphthalen-1-yl-2-(2-oxo-1,2dihydro-indol-3-ylidene)-acetamide (connection 18) ex tempore were suspended in water for injections to use an emulsifier "Tvin -80" (1 drop and $10 \mathrm{mg}$ of substance) and were administered into animals intraperitoneally in toxic dosage $(4.3 \mathrm{mg} / \mathrm{kg}$ and $12 \mathrm{mg} / \mathrm{kg}$ ) about diazepam for $1 \mathrm{~h}$ to intake GABA, ergic ligands. It was used korazol (Sigma-Aldrich, USA) in the dosage of $80 \mathrm{mg} / \mathrm{kg}$ of human's weight, blocker $\mathrm{Cl}^{-}$of chloric channel of $\mathrm{GABA}_{\mathrm{A}}$-receptor of complex, piktrotoxin (Sigma-Aldrich, USA) in the dosage of $5 \mathrm{mg} / \mathrm{kg}$ of human's weight is a model antagonist $\mathrm{GABA}_{\mathrm{A}}$-receptors which blocks activated GABA of tokion's chlorine through a receptor and bikukullin (Sigma-Aldrich, USA) in the dosage of $5 \mathrm{mg} / \mathrm{kg}$, is classical allosteric inhibitor of low-affinity $\mathrm{GABA}_{\mathrm{A}}$-receptors. Analyzers of synaptic transmission were administered subcutaneously in the area of cervical region of back. In experiments diazepam was used ("Tarchomin S.A.", Poland), it is an agonist benzodiazepine receptors which increases frequency of opening chloric channel of $\mathrm{GABA}_{\mathrm{A}}$-receptor in the dosage of $2 \mathrm{mg} / \mathrm{kg}$ of human's weight.

An intake of pikrotoxin, korazol and bikukullin is followed by a development of convulsing syndrome, which was estimated according indexes: latent period of convulsions (sec.), number of convulsion's acts, duration of convulsions (sec.) and number of survived animals in group. Also it was studied an intensity of convulsion attack development due to 6-grade scale [9]: 0 is an absence of convulsion's activity; 1 is hyperkinesia; 2 is shake, twitch; excessive grooming, stereotypic movements; 3 is clonic convulsions of the 
front paws with rise on the back ones; 4 is expression of tonic and clonic convulsions, falling down on the flank, a presence of phase of tonic extension; 5 are repetitive clonic and tonic convulsions, loss of pose, 6 is complete tonic attack with apnea, animal's death. It has been estimated an ability to depress clonic and tonic convulsions, to increase latent period, to decrease number, to reduce general duration of convulsive syndrome and mortality of animals.

Statistic analyses of investigation was provided due to such programmes: Statistica 6.0 (StatSoft, Inc., USA) and use of dispersive analysis ANOVA and criteria $\chi^{2}[10]$. A comparison of received results was performed using t-criteria Styudent, changes were estimated right at $\mathrm{p} \leq 0.05$.

\section{Results and their Discussion}

An influence of 2-oksoindolin-3-glyoxylic acid derivatives on GABA, ionofor-receptor complex was estimated on the model of korazol, pikrotoxic and bikukullin experimental convulsive syndrome to its ability to modify clinical picture of intoxication.

The first stage of experiments showed that korazol's intake in the dosage of $80 \mathrm{mg} / \mathrm{kg}$ caused a development of convulsive syndrome. A mortality of animals contained $50 \%$ (Table 1 ).

During intensity of convulsive attack after korazol intake it was indicated, convulsions increased in 1,5 times in comparison with convulsant's intake without pharmocoprevention $(\mathrm{p}<0.001)$ (Fig. 1). Also reference-preparation increased time of latent of convulsion's development and increased a number of convulsive acts in 1.8 times in comparison with control pathology $(\mathrm{p}<0.001)$ (Table 1). Prophylactic diazepam intake increased a duration of convulsive period in animals in 2 times and mainly reduced animal's mortality in comparison with $\mathrm{GABA}_{\mathrm{A}}$-blocker without correction $(\mathrm{p}<0.001)$ (Table 1).

In the result of given investigations it was indicated that preventive intake of 2-oksoindolin-3-glyoxylic acid derivatives E-38 cannot cause statistic changes of none of indexes of convulsion' $\mathrm{s}$ development syndrome and causes anticonvulsive action at convulsions which are caused by korazol's intake.

Preventive usage of a substance with lab cipher 18 is analogically to reference-preparation reduced intensity of korazol's convulsive syndrome in animals in 1.7 times in comparison with control pathology $(\mathrm{p}<0.001)$ (Fig. 1). An intake of combination 18 increased a duration of latent period from the beginning of convulsions in 1.9 times in comparison with control pathology $(\mathrm{p}<0.001)$. At this time number of convulsive acts reduced in animals. (Table 1). After reproduction of chemo-induced korazol of epileptogenesis, substance 18 decreased a duration of convulsive period in animals in 2.3 times in comparison with animals without intake of 2-oksoindolin derivative $(\mathrm{p}<0.001)$. Also in this experimental group it is not observed mortality after convulsant's intake (Table 1).

During the second stage of experiments, a development of convulsive pathology in experimental animals were modeled by intake of pikrotoxin in the dosage of $5 \mathrm{mg} / \mathrm{kg}$. After pikrotoxin's intake, as a model antagonist of $\mathrm{GABA}_{\mathrm{A}}$-receptors in animals developed classical convulsive syndrome, which showed

Table 1 An influence of 2-oksoindolin-3-glyoxylic acid derivatives and diazepam on convulsions which was caused by korazol intake (80 $\mathrm{mg} / \mathbf{k g}), \mathrm{M} \pm \mathrm{m}$.

\begin{tabular}{lllll}
\hline $\begin{array}{l}\text { Group of animals } \\
\mathrm{n}=10\end{array}$ & $\begin{array}{l}\text { Latent period of } \\
\text { convulsions }(\mathrm{s})\end{array}$ & $\begin{array}{l}\text { Number of convulsive } \\
\text { acts }(\mathrm{s})\end{array}$ & $\begin{array}{l}\text { Duration of convulsions } \\
(\mathrm{s})\end{array}$ & $\begin{array}{l}\text { Animal's mortality in a } \\
\text { group }\end{array}$ \\
\hline 1. Control pathology & $312.5 \pm 26.8$ & $10.6 \pm 0.84$ & $2,800 \pm 296$ & $10 / 5$ \\
2. Diazepam, $2 \mathrm{mg} / \mathrm{kg}$ & $417.5 \pm 29.3$ & $5.9 \pm 0.43$ & $1,409 \pm 123$ & $10 / 1$ \\
$\mathrm{P}_{1-2}$ & $<0.02$ & $<0.001$ & $<0.001$ & $>0.25\left(\chi^{2}\right)$ \\
4. Substance E-38 & $374.7 \pm 32.9$ & $10.1 \pm 0.84$ & $1,437 \pm 174$ & $10 / 5$ \\
$\mathrm{P}_{1-3}$ & $>0.25$ & $>0.25$ & $<0.001$ & $>0.25\left(\chi^{2}\right)$ \\
5. Substance 18 & $603.2 \pm 30.9$ & $5.1 \pm 0.54$ & $1,208 \pm 60$ & $10 / 1$ \\
$\mathrm{P}_{1-4}$ & $<0.001$ & $<0.001$ & $<0.001$ & $>0.25\left(\chi^{2}\right)$ \\
\hline
\end{tabular}




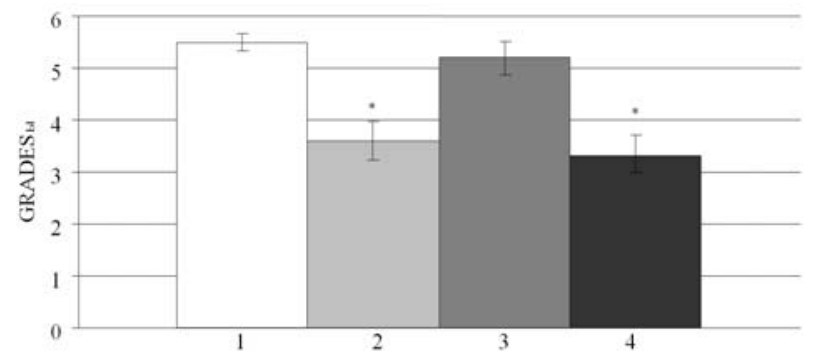

Fig. 1 An influence of 2-oksoindolin-3-glyoxylic acid derivatives and diazepam on convulsion's intensity at korazol's intake (80 $\mathrm{mg} / \mathrm{kg})$. *P $\leq \mathbf{0 . 0 5}$.

(1) Control pathology; (2) Diazepam, $2 \mathrm{mg} / \mathrm{kg}$; (3) Substance E-38; (4) Substance 18.

$100 \%$ of animal's mortality (Table 2).

Under influence of diazepam convulsive syndrome modified significantly which was caused by pikrotoxin. There was a decrease of convulsions in animals in 1.4 times in comparison with convulsant's intake without pharmacoprevention $(\mathrm{p}<0.001)$ (Fig. 2). Also preventive usage of diazepam increased latent period of convulsion's start in 2.4 times $(\mathrm{p}<0.001)$ and decreased a number of convulsions in 1.7 times $(\mathrm{p}<$ 0.002) in comparison with control pathology. An intake of classical tranquilizer diazepam on the background of pikrotoxin prevented a mortality of animals (Table 2).

At analysis of anticonvulsive action of 2-oksoindolin derivatives it is important to note substance E-38 did not influence on studied parameters of convulsive pikrotoxin syndrome.

On the background of pikrotoxin's intake combination 18, analogically to preparation of comparison diazepam, decreased a severity of convulsive syndrome in experimental animals effectively and veraciously (Fig. 2). 2-oksoindolin derivatives with lab cipher 18 prolonged a latent period of the beginning of convulsions in 2 times in comparison with convulsant's intake without correction $(\mathrm{p}<0.001)$. Also preventive substance's intake 18 decreased a number of convulsions in 1.9 times $(\mathrm{p}<0.001)$. In animals a duration of convulsive period decreased and it was not registered lethal issues in comparison with control pathology (Table 2).

During next stage of experiments it was studied an influence of 2-oksoindolin-3-glyoxylic acid derivatives on convulsive action of bikukullin. An inhibitor's intake of low-affinity of $\mathrm{GABA}_{\mathrm{A}}$-receptors caused a development of convulsive syndrome in animals, which was over lethally in half cases.

Diazepam's intake before convulsant's use decreased an intensity of convulsive syndrome in comparison with control pathology (Fig. 3). Diazepam prolonged at period of convulsion's start in 1.3 times in comparison with control pathology $(p<0.001)$ (Table 3). Also preparation of comparison decreased a number and duration of convulsive acts.

Preventive of an intake of E-38 combination did not have an influence on intensity, latent period, number and duration of convulsive acts on the background of bikukullin's intake. At that time a substance with lab cipher 18 decreased a manifestation of convulsive syndrome. Protective action of 2-oksoindolin derivative demonstrated an increase of latent period of the convulsion's start in 1.2 times in comparison with control pathology $(p<0.01)$. At that time combination 18 decreased a duration of convulsive syndrome in comparison with bikukullin's intake without pharmocorrection (Table 3 ). Received results of this

Table 2 An influence of 2-oksoindolin-3-glyoxylic acid derivatives and diazepam on convulsions which was caused by pikrotoxin's intake (5 mg/kg), M $\pm \mathrm{m}$

\begin{tabular}{lllll}
\hline $\begin{array}{l}\text { Group of animals } \\
\mathrm{n}=10\end{array}$ & $\begin{array}{l}\text { Latent period of } \\
\text { convulsions }(\mathrm{s})\end{array}$ & $\begin{array}{l}\text { Number of convulsive } \\
\text { acts }(\mathrm{s})\end{array}$ & $\begin{array}{l}\text { Duration of convulsions } \\
(\mathrm{s})\end{array}$ & $\begin{array}{l}\text { Animal's mortality in a } \\
\text { group }\end{array}$ \\
\hline 1. Control pathology & $510.4 \pm 35.7$ & $12.1 \pm 1.10$ & $1,975 \pm 115$ & $10 / 10$ \\
2.Diazepam, $2 \mathrm{mg} / \mathrm{kg}$ & $1,200 \pm 50.7$ & $7.33 \pm 0.62$ & $1,719 \pm 162$ & $10 / 0$ \\
$\mathrm{P}_{1 \text {-2 }}$ & $<0.001$ & $<0.002$ & $>0.25$ & $<0.001\left(\chi^{2}\right)$ \\
3.Substance E-38 & $541.6 \pm 37.5$ & $12.8 \pm 1.2$ & $1,984 \pm 85.4$ & $10 / 9$ \\
$\mathrm{P}_{1 \text {-3 }}$ & $>0.25$ & $>0.25$ & $>0.25$ & $>0.25\left(\chi^{2}\right)$ \\
4. Substance 18 & $1,009 \pm 41.4$ & $6.4 \pm 0.52$ & $1,674 \pm 95.0$ & $10 / 0$ \\
$\mathrm{P}_{1-4}$ & $<0.001$ & $<0.001$ & $<0.1$ & $<0.001\left(\chi^{2}\right)$ \\
\hline
\end{tabular}


Table 3 An influence of 2-oksoindolin-3-glyoxylic acid derivatives and diazepam on convulsion's intake of bikukullin (5 $\mathbf{m g} / \mathbf{k g}), \mathbf{M} \pm \mathbf{m}$.

\begin{tabular}{lllll}
\hline $\begin{array}{l}\text { Group of animals } \\
\mathrm{n}=10\end{array}$ & $\begin{array}{l}\text { Latent period of } \\
\text { convulsions }(\mathrm{s})\end{array}$ & $\begin{array}{l}\text { Number of convulsive } \\
\text { acts }(\mathrm{s})\end{array}$ & $\begin{array}{l}\text { Duration of convulsions, } \\
(\mathrm{s})\end{array}$ & $\begin{array}{l}\text { Animal's mortality in a } \\
\text { group }\end{array}$ \\
\hline 1. Control pathology & $165.4 \pm 6.78$ & $9.3 \pm 0.84$ & $2,328.4 \pm 105$ & $10 / 5$ \\
2.Diazepam, $2 \mathrm{mg} / \mathrm{kg}$ & $214.9 \pm 10.0$ & $6.1 \pm 0.45$ & $1,785 \pm 116$ & $10 / 2$ \\
$\mathrm{P}_{1 \text {-2 }}$ & $<0.001$ & $<0.01$ & $<0.01$ & $>0.25\left(\chi^{2}\right)$ \\
3. Substance E-38 & $181.1 \pm 9.48$ & $8.8 \pm 0.83$ & $2,385 \pm 123$ & $10 / 6$ \\
$\mathrm{P}_{1-3}$ & $>0.25$ & $>0.25$ & $>0.25$ & $>0.25\left(\chi^{2}\right)$ \\
4. Substance 18 & $198.9 \pm 7.08$ & $8.3 \pm 0.82$ & $1,975 \pm 102$ & $10 / 4$ \\
$\mathrm{P}_{1-4}$ & $<0.01$ & $>0.25$ & $<0.05$ & $>0.25\left(\chi^{2}\right)$ \\
\hline
\end{tabular}

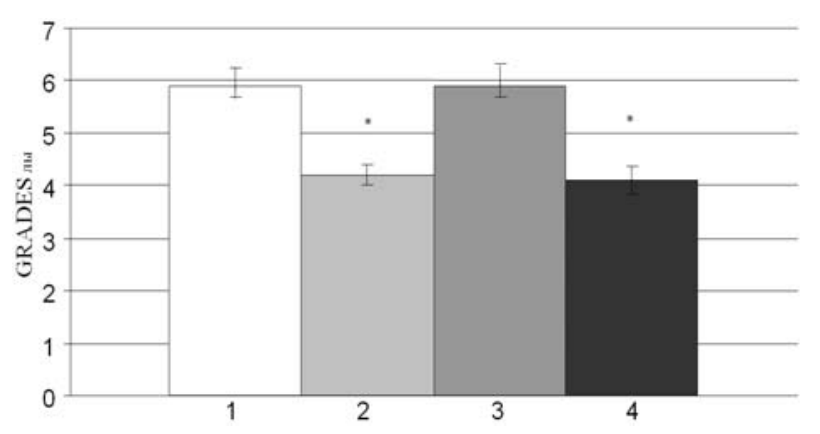

Fig. 2 An influence of 2-oksoindolin-3-glyoxylic acid derivatives and diazepam on convulsion's intensity which was caused by pikrotoxin's intake $(5 \mathrm{mg} / \mathrm{kg}) .{ }^{*} \mathbf{P} \leq \mathbf{0 , 0 5}$.

(1) Control pathology; (2) Diazepam, $2 \mathrm{mg} / \mathrm{kg}$; (3) Substance E-38; (4) Substance 18.

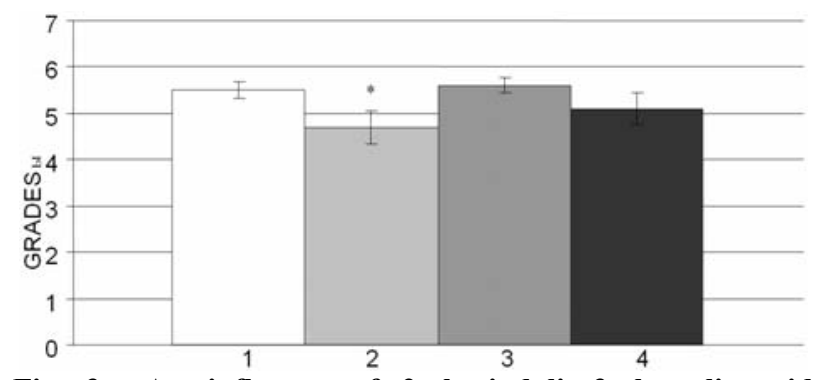

Fig. 3 An influence of 2-oksoindolin-3-glyoxylic acid derivatives and diazepam on convulsion's intake of bikukullin (5 mg/kg).

(1) Control pathology; (2) Diazepam, $2 \mathrm{mg} / \mathrm{kg}$; (3) Substance E-38; (4) Substance 18.

stage of animals testify that 2-oksoindolin-3-glyoxylic acid derivative (substance 18) decreased a manifestation of convulsive bikukullin's activity in the extension of convulsion's start and increased a duration of convulsions.

In the result of performed experiments, it was indicated a combination E-38 does not have an influence on a severity of convulsive syndrome at korazol's, pikrotoxin's, bikukullin's intake. It allows suggesting an absence of interrelation of this substance with subunits of $\mathrm{GABA}_{\mathrm{A}}$-receptor complex .

Preventive intake of 2-oksoindolin derivative, substance with lab cipher 18, modified greatly a clinical picture of intoxication which was caused by korazol's pikrotoxin's, bikukullin's intake, that demonstrated a decrease of intensity of convulsive syndrome, an increase of latent period of convulsions, reduction of number and duration of convulsions, in prevention animal's mortality. So, efficacy of anticonvulsive action of substance 18 at pharmacological chemo-induced epileptogenesis is a predictor its effectiveness at convulsive pathology in patients at clinic, especially at absence seizures and reduced forms of epilepsy.

Proconvulsive action of pikrotoxin and korazol is connected with inhibition of $\mathrm{GABA}_{\mathrm{A}}$-receptors on the blocker's level chloric currents through ionofor [11]. Considering that a presence of specific site of receptor convulsive action of korazol is closely connected with blocker and changes in the structure of $\mathrm{GABA}_{\mathrm{A}}$-receptors [12]. Received data allow suggesting, a decrease of convulsive syndrome under an influence of 2-oksoindolin derivative is determined by definite modulation and condition of $\mathrm{GABA}_{\mathrm{A}}$-receptors, which caused convulsive agents.

Also, anticonvulsive action of 2-oksoindolin derivative has competitive and simulated allosteric interrelations, which are determined by conformational changes in area of ionofor of $\mathrm{GABA}_{\mathrm{A}}$-receptor. Such hypothesis can be considered, whereas combination 18 was inserted in prophylactic way, and it is able to cause changes in sites of 
convulsants, that caused following decrease of ability of $\mathrm{GABA}_{\mathrm{A}}$-blockers. However such interrelation should not studied as direct opposition and displacement of convulsants in sites of their combination.

Other possible mechanism of anticonvulsive action of 2-oksoindolin derivative can be determined by ability to modify and influence on serotonin in CNS, which has been showed by us in previous investigations. Present hypothesis is approved by interrelation between GABA-ergic and serotonin and ergic systems on the level of pyramidal cells of brain [13], and also ability of agonists of serotonin $1 \mathrm{~A}$, receptors modify experimental convulsive syndrome [14] as it was showed for other indole derivatives. It should be noted a release of serotonin in neuronal network of brain is regulated by brake GABA-ergic interneurons [15]. Blockage of $\mathrm{GABA}_{\mathrm{A}}$-receptors of proconvulsants causes a decrease of brake influence on serotonin's output, that leads to an increase of serotonin's output.

\section{Conclusions}

In the result of performed investigations it was indicated, at preventive intake of 2-oksoindolin-3-glyoxilic acid derivatives combination 2-hydroxy-N-naphthalen-1-yl-2-(2-oxo-1,2-dihydro-in dol-3-ylidene)-acetamide in the dosage $12 \mathrm{mg} / \mathrm{kg}$ effectively decreased a manifestation of convulsive syndrome. It demonstrated a decrease intensity of convulsive syndrome, increase of latent period of convulsion's start, which was caused by korazol's, pikrotoxin's, bikukullin's intake, decrease of number of convulsive acts on the background of korazol and pikrotoxin, decrease of duration of convulsive syndrome during korazol's and bikukullin's intake, and also decrease of animal's mortality which was caused by pikrotoxin's intake. Received results show a presence of 2-oksoindolin derivative anticonvulsive activity in mechanisms that plays direct or indirect role of GABA-ergic system.

\section{References}

[1] M.L. López-Meraz, M.E. González-Trujano, L. Neri-Bazán, E. Hong, L.L. Rocha, 5-HT1A receptor agonists modify epileptic seizures in three experimental models in rats, Neuropharmacology 49 (3) (2005) 367-375.

[2] A. Wesołowska, A. Nikiforuk, E. Chojnacka-Wójcik. Anticonvulsant effect of the selective 5-HT1B receptor agonist CP 94253 in mice, Eur. J. Pharmacology 541 (1-2) (2006) 57-63.

[3] H.U. Wittchen, F. Jacobi, J. Rehm, A. Gustavsson, M. Svensson, B. Jönsson, et al., The size and burden of mental disorders and other disorders of the brain in Europe 2010, Eur. Neuropsychopharmacol 21 (9) (2011) 655-679.

[4] S.T. Syunyakov, S.A. Syunyakov, O.A. Dorofeeva, Mechanisnis of genesis and anxiety therapy, Psychiatry and Psychofarmotherapy13 (6) (2011) 9-16.

[5] N.A. Maruta, M.V Shestakova, Clinical and psychopathological structure of depression in older adults with suicidal behavior, Clinical psychiatry 13 (48) (2009) 8-15.

[6] L. Pozuelo, G. Tesar, J. Zhang, Depression and heart disease: What do we know, and where are we headed? Cleveland Clinic Journal of Medicine 76 (1) (2009) 59-70.

[7] A.G. Richard, Strategies for the Development of Selective Serotonergic Agents, The Serotonin Receptors, Molecular Pharmacology to Human Therapeutics, Humana Press, 2006, p. 618.

[8] T. Hiromitsu, Chemistry and Pharmacology of Analgesic Indole Alkaloids from the Rubiaceous Plant, Mitragyna speciosa, Chem. Pharm. Bull 52 (8) (2004) 916-928.

[9] M.C. Gerald, W.H. Riffee, Acute and chronic effects of dand 1-amphetamine on seizure susceptibility in mice, Eur. J. Pharmacology 21 (3) (1973) 323-330.

[10] V.Ya. Gel'man, Medizinskaya Informatika: Praktikum, SPb, Piter, 2001, p. 468.

[11] R.Q. Huang, C.L. Bell-Horner, M.I. Dibas, D.F. Covey, J.A. Drewe, G.H. Dillon, Pentylenetetrazole-induced inhibition of recombinant $\gamma$-aminobutyric acid type A $\left(\mathrm{GABA}_{\mathrm{A}}\right)$ receptors: Mechanism and site of action, The Journal of Pharmacology and Experimental Therapeutics 298 (3) (2001) 986-995.

[12] JO Oni, OE Awe, AO Olajide, MJ Makinde. Anticonvulsant and depressant activities of the seed extracts of Adnanthera parvonina. Journal of Natural Products 2 (2009) 74-80.

[13] D.C. D'Souza, R.B. Gil, E. Zuzarte, L.M. MacDougall, L. Donahue, J.S. Ebersole, et al., $\gamma$-Aminobutyric acid-serotonin interactions in healthy men: implications for network models of psychosis and dissociation, Biol. 
Psychiatry 59 (2006) 128-137.

[14] M. Jung, H. Lal, M. Gat, The discriminative stimulus effects of pentylenetetrazol as a model of anxiety: Recent developments, Neurosci Biobehav. Rev. 26 (4) (2001) 429-439.
[15] S. Clements, C.B. Schreck, Evidence that GABA mediates dopaminergic and serotonergic pathways associated with locomotor activity in juvenile chinook salmon (Oncorhynchus tshawytscha), Behav. Neurosci. 118 (1) (2004) 191-198. 